\title{
Bombax costatum (Malvaceae): state of knowns, unknowns and prospects in West Africa
}

\author{
Gnido Amandine Assogba ${ }^{(1)}$, Adandé Belarmain Fandohan ${ }^{(1,2,3)}$, Kisito Gandji ${ }^{(3)}$, \\ Valère Kolawolé Salako ${ }^{(3)}$, Achille Ephrem Assogbadjo ${ }^{(1,3)}$ \\ (1) Université d'Abomey Calavi. Faculté des Sciences Agronomiques. Laboratoire d'Écologie Appliquée. 06 BP 3529. \\ Cotonou (Benin).E-mail: sedjro11@gmail.com \\ (2) Université Nationale d'Agriculture. École de Foresterie et Ingénierie du Bois. Unité de Recherche en Foresterie, \\ Agroforesterie et Biogéographie. BP 43. Kétou (Bénin). \\ (3) Université d'Abomey Calavi. Faculté des Sciences Agronomiques. Laboratoire de Biomathématiques et d'Estimations \\ Forestières. 04 BP 1525. Cotonou (Bénin).
}

Received 20 March 2018, accepted 18 Septembre 2018, available online 4 October 2018.

This article is distributed under the terms and conditions of the CC-BY License (http://creativecommons.org/licenses/by/4.0)

Introduction. The red kapok tree, Bombax costatum is a tree species native to West Africa. Most of its organs or plant parts are of medicinal, food, and economic importance.

Literature. The species is widely used for food and medicinal purposes and as timber. Yet B. costatum is poorly studied and declining across its distribution range. So far, little has been achieved on this species'conservation status, genetic diversity, breeding and domestication. With the aim of synthesizing current knowledge and gaps, and suggesting future research, articles were searched in Google Scholar and Web of Science databases with relevant keywords on B. costatum. All articles found were critically read and analyzed for inclusion in the present review.

Conclusions. The current state of knowledge on taxonomy, distribution, ecology, botanical description, structural characteristics, uses, nutritional and phytochemical properties, socioeconomic importance, propagation, growth and development, threats and conservation of $B$. costatum have been reviewed. Knowledge gaps were identified and research and development avenues were suggested and discussed for conservation of this species.

Keywords. Bombax costatum, taxonomy, ecology, ethnobotany, nature conservation.

\section{Bombax costatum (Malvaceae) : état des connaissances et perspectives en Afrique de l'Ouest}

Introduction. Le kapokier rouge (Bombax costatum) est une espèce originaire d'Afrique de l'Ouest. La plupart de ses organes ou parties de plante sont d'une grande importance médicinale, alimentaire et économique.

Littérature. L'espèce est majoritairement utilisée pour l'alimentation, la médecine traditionnelle et comme bois d'œuvre. Malgré cela, B. costatum est très peu étudié et son aire de répartition se réduit de plus en plus. En outre, très peu de travaux ont été menés sur la conservation, la diversité génétique, l'amélioration génétique et la domestication de l'espèce. Dans le but de synthétiser les connaissances existantes, d'identifier les lacunes de ces connaissances sur l'espèce et de proposer des perspectives de recherches futures, des articles ont été recherchés dans les bases de données Google Scholar et Web of Science. Tous les articles trouvés ont fait l'objet de lecture critique et d'analyse afin de les inclure dans la présente synthèse bibliographique.

Conclusions. Les connaissances actuelles sur la taxonomie, la distribution, l'écologie, la description botanique, les caractéristiques structurales, les différentes utilisations, les propriétés nutritionnelles et phyto-chimiques, l'importance socioéconomique, la propagation, la croissance et le développement, les menaces et la conservation de $B$. costatum ont été résumées et analysées. Les lacunes ont été identifiées et les axes de recherche-développement ont été suggérés et discutés en vue de la conservation durable de l'espèce.

Mots-clés. Bombax costatum, taxonomie, écologie, ethnobotanique, conservation de la nature. 


\section{INTRODUCTION}

Importance of biodiversity for human well-being is multi-fold, including but not restricted to, providing timber and non-timber forest products (NTFPs) for multiple uses (Millennium Ecosystem Assessment, 2005). The contribution of the resident flora and fauna to rural communities' livelihoods in Western Africa, as food, medicine, energy, timber and income generator has been thoroughly reviewed (Boffa, 2000; Kristensen \& Lykke, 2003; Lykke et al., 2002; Heubach, 2011; Sieglstetter et al., 2011). For instance, the majority of rural communities live on less than US \$1 per day in Sub-Saharan Africa (World Bank, 2004; FAO, 2005) and sustain their livelihoods from forests through extensive land cultivation, tree logging and over-utilization of NTFPs. Because these activities are not properly managed and monitored, they have contributed to the degradation of the natural environments of several NTFPs.

Many NTFPs in the tropics such as Bombax costatum Pellegr. \&Vuillet are under threat mainly because of over-harvesting by rural communities and a lack of conservation policies that undermine their sustainable management. There are also underlying causes such as governance issues, insecure use rights, rural poverty, agricultural policies and a lack of active involvement of rural communities in the development of policies regarding the bio resources they depend on. Bombax costatum is a threatened species partly because of its poor regeneration (Ouédraogo et al., 2006), caused by intensive harvesting of its flowers for domestic and commercial use as a vegetable (Belem et al., 2008). It is much used for food and medicinal purposes and as timber. Recent ethnobotanical assessments conducted on B. costatum in Benin and Burkina Faso, two westAfrican countries, enumerated eight use categories of which food and medicinal purposes were the most frequently cited and the most culturally important (Belem et al., 2008; Assogba et al., 2017).

Despite increasing endeavours to document the uses and socioeconomic importance of B. costatum and its regeneration potential in Western African countries, the gap of scientific knowledge of the species is still great. As an example, B. costatum does not appear either on the list of plants used for food in tropical Africa (Grubben \& Denton, 2004), nor in the report on the biodiversity of leafy vegetables (Chweya \& Eyzaguire, 1999). In the current context of climatesmart-agriculture, countries in regions expected to face drastic changes in the climate have to explore and identify best species that will facilitate adaptation of agriculture to the climate change (Fandohan et al., 2015). From an ecosystem-based adaptation to climate change perspective, indigenous wild edible plants such as B. costatum will play a strategic role in climate-smart-agriculture in the West African region (Fandohan et al., 2015). A first step towards this is that target species should be studied and documented to ensure science-based policies and decisions.

The present review aims to summarize the current knowledge on B.costatum (taxonomy, distribution, ecology, botanical description, structural characteristics, uses, nutritional and phytochemical characteristics, socioeconomic importance, propagation, growth, threats and conservation) in West Africa, identify gaps in knowledge and discuss research and development avenues for conservation of this species.

\section{METHODOLOGY}

Searches were conducted using electronic databases (Google Scholar and Web of Science) and general web searches using Google. The following related search terms were used: taxonomy, distribution, ecology, botanical description, structural characteristics, uses, nutritional and phytochemical value, economy, propagation, growth and development, threats and conservation, and domestication in combination with $B$. costatum as a keyword within the title of the article. All the searched articles were critically read and peerreviewed articles presenting results of experimental studies on the species were analyzed. Of the 67 articles found, 43 were considered in the present review.

\section{TAXONOMY, GEOGRAPHICAL DISTRIBUTION AND ECOLOGY}

Bombax is a pantropical genus of the Malvaceae (order Malvales), comprising eight species: two in Africa, five in Asia, and one from Asia to the Solomon Islands (Robyns, 1957; Orwa et al., 2009). Bombax costatum Pellegr. \& Vuillet is one of these species popularly known as "red-flowered silk-cotton tree", "red kapok tree", and "Gambia silk-cotton tree". This species is also known by other common and vernacular names: "kapokier à fleurs rouges", "fromager", "kapokier rouge", "faux kapokier", "kapokier de forêt" (France); "kattupa", "garablaobe" (Senegal); "huntin" and "forgo" (Benin) (Akoègninou et al., 2006).

Bombax costatum is native and distributed in savanna zones in Western Africa from Chad to Mauritania (Orwa et al., 2009; Ouédraogo et al., 2014; GBIF, 2017). It is a characteristic tree of savannas and dry woodlands of the Sudanian zone of West Africa, extending to the north into the Sahelian zone and to the south into the Guinean zone (Aubréville, 1950; Arbonnier, 2002; see figure 1). The species is occasionally cultivated in West Africa for its edible calyx (Achigan-Dako et al., 2010). Generally, 


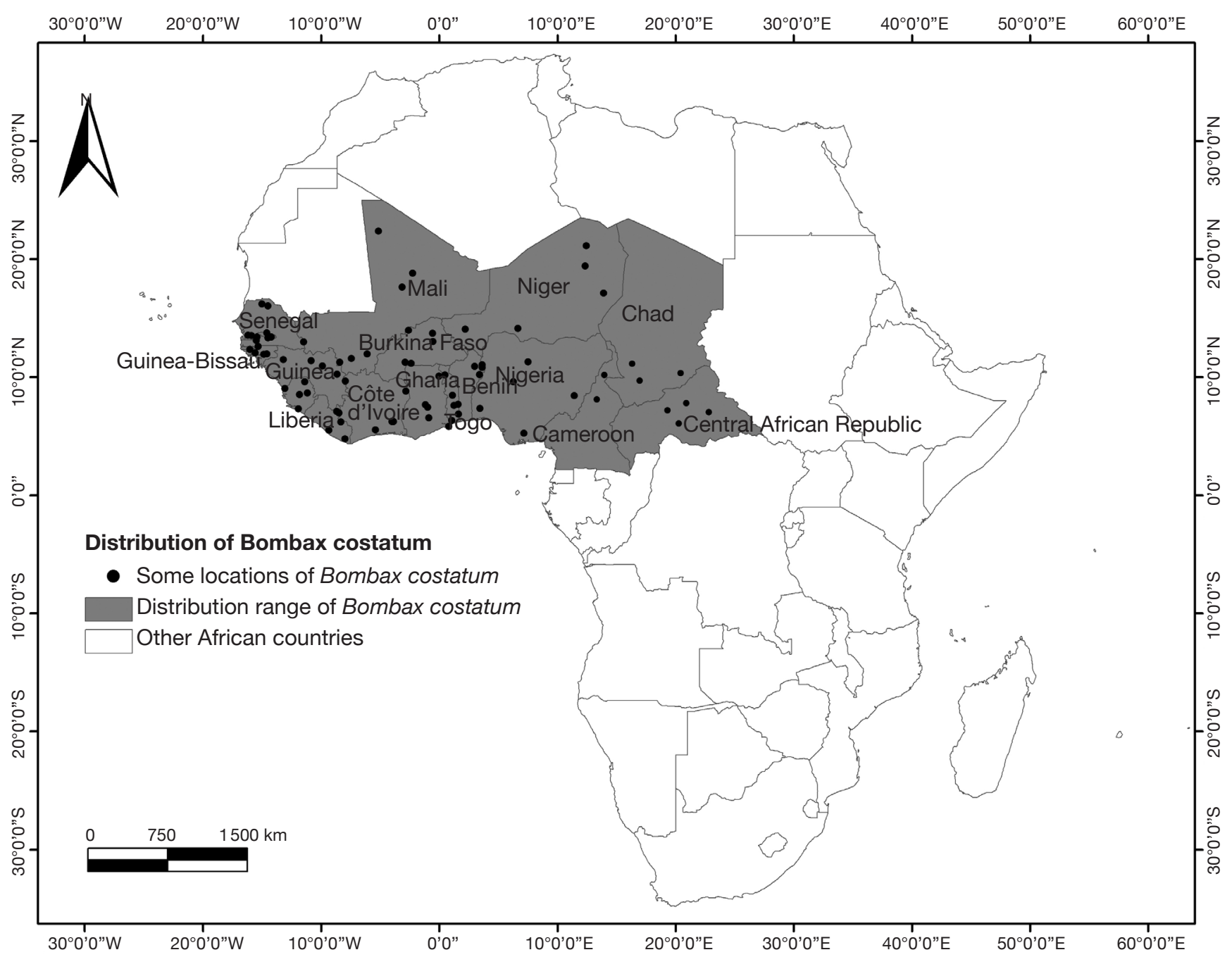

Figure 1. Distribution of Bombax costatum Pellegr. \& Vuillet in West Africa (adapted from Oyen, 2011 \& http://www.hombori.org/english/biodiversity/flora.html, 22/07/2018) - Distribution de Bombax costatum Pellegr. \& Vuillet en Afrique de l'Ouest (adapté de Oyen, 2011 \& http://www.hombori.org/english/biodiversity/flora.html, 22/07/2018).

B. costatum occurs in regions with $800-1,500 \mathrm{~mm}$ mean annual rainfall. In Burkina Faso, it grows in areas with 600-900 $\mathrm{mm}$ annual rainfall (Belem, 2009). It grows on stony and gravelly lateritic soils, and often in cropland, close to settlements (Oyen, 2011) and in parklands (Bayala et al., 1995). Individual trees which can reach $17 \mathrm{~m}$ are often observed along temporary stream banks on clay-sandy soils. Bombax costatum is a fire resisting species with tuberous roots acting as water and/or sugar storage during long drought periods (Orwa et al., 2009). In the wild, B. costatum is usually associated with Pterocarpus erinaceus Poir., Daniellia oliveri (Rolfe) Hutch. \& Dalziel, Cordyla pinnata (Lepr. ex A.Rich.) Milne-Redh., Terminalia macroptera Guill. \& Perr., and Prosopis africana (Guill. \& Perr.) Taub. (Orwa et al., 2009). In dry forests of the Guinean zone, B. costatum is replaced with Bombax buonopozense P.Beauv. and in wetter forests with Bombax brevicuspe
Sprague (Oyen, 2011). In the literature there is a lack of knowledge regarding the species'distribution and associated environmental conditions.

\section{BOTANICAL DESCRIPTION AND STRUCTURAL CHARACTERISTICS}

Bombax costatum is a deciduous tree that grows between 10 and $25 \mathrm{~m}$ height in relatively wet conditions (Ouédraogo et al., 2014), but hardly reaches over $6 \mathrm{~m}$ in the Sahel (Orwa et al., 2009). With a straight bole, it can reach $60 \mathrm{~cm}$ in diameter, and is sometimes buttressed. The crown structure of young trees is storeyed, becoming irregular and sturdy in older trees. The bark is thick, grey brown and corky, with typical conical, stout, sharp-pointed spines on the stem and branch, and with a light red brown slash (Orwa et al., 2009). 
Leaves are digitate compound, with 5-7 leaflets, 8-15 cm long (Oyen, 2011) and 10-18 cm long with petiolules up to $5 \mathrm{~mm}$ long (Orwa et al., 2009). Leaflets are partly ovate, and acuminate at both ends, with 8-10 pairs of lateral nerves. Flowers are 5-6 cm long and solitary, deep red, orange or yellow, tulip shaped, on long, glabrous peduncles with the calyx cup-shaped. The fruit, an ellipsoidal capsule, is dark brown to brown, and composed of 5 valves, dehiscent, $8-16 \mathrm{~cm}$ long and 3-6 cm wide, of variable shape (Orwa et al., 2009). The fruit contains white floss, called kapok and several small seeds. Seeds are globose to pear-shaped, 4-5 $\mathrm{mm}$ in diameter, dark brown to black, embedded in the white floss (Oyen, 2011).

The spatial distribution of $B$. costatum is generally characterized by scattered individuals in both protected and anthropogenized natural stands (Ouédraogo et al., 2014). In the Sudanian zone, the natural stands are sometimes large with a density of 6-10 trees per $1,000 \mathrm{~m}^{2}$. Reportedly, natural stands of this species in drier conditions tend to show relatively many large stems and few smaller stems (Ouédraogo, 2006).

\section{USES, NUTRITIONAL, PHYTOCHEMICAL PROPERTIES AND SOCIOECONOMIC IMPORTANCE}

\subsection{Food uses}

Bombax costatum is among the most used and important wild vegetable species (Mertz et al., 2001; Lykke et al., 2002). The calyx is the plant organ most frequently used especially for food (Ouédraogo et al., 2014; Assogba et al., 2017). This also appears as the most common use of $B$. costatum across its natural range (Figure 2). Leaves and the fleshy calyx of the flowers are cooked and eaten as a vegetable (Lykke et al., 2002). Bombax costatum is recorded as the second most preferred sauce species in rural Burkina Faso (Lykke et al., 2002). Unripe fruits and flowers are added to sauces to thicken them (Oyen, 2011). The young fruit is harvested around August and September, dried and used for the preparation of meals (Orwa et al., 2009). The young, unripe fruit is also used in the preparation of a beverage while the seed oil is suitable for consumption (Oyen, 2011).

\subsection{Medicinal uses}

Several parts of the tree are used in traditional medicine against a great variety of illnesses. Various parts are used against fever or to promote lactation in women and as tonic for tiredness (Orwa et al., 2009). In Senegal and Sierra Leone, diuretic properties are attributed to the bark of stem and roots (Oyen, 2011). The powdered root is macerated and eaten in a sauce or applied as a bath against epilepsy (Oyen, 2011). Roots and bark are much used for the treatment of dizziness, dysentery and malaria in Burkina Faso (Belem et al., 2008). The bark is used for the treatment of skin diseases, yellow fever and headache. Bark preparations are applied to wounds to facilitate healing. A bath in an extract of the stem bark is taken against insanity (Oyen, 2011). The latter argued that the powdered stem bark is used in a medicine applied as a fumigant against headache. The bark is also used for the treatment of skin diseases. In Benin, this species bark is used against fever, skin disease, pain, abscess, oedema, hernia, and epilepsy (Assogba et al., 2017). In Mali, a decoction of the bark and leaves and parts of other plants is taken against menstrual problems (Inngjerdingen et al., 2004). A warm bath in a decoction of leaves may be prescribed to feverish patients, especially children. The leaves are often prescribed with other drugs derived from plants against leucorrhoea and diarrhoea in Senegal (Oyen, 2011). An extract of ground leaves is drunk against problems during childbirth and a bath in this extract is taken repeatedly for the treatment of convulsions. The tea derived from dried leaves is drunk or applied to the body against measles. The leaf decoction is also given to children as a drink for the treatment of rickets. The leaves and immature fruit are used as emollient. A decoction of leaves, root or stem bark is drunk in cases of serious oedema (Oyen, 2011). Leaves mixed with shea butter are rubbed onto affected skin against leprosy. Leaves ground in water are given to sheep against snake bites. Maceration of pounded leaves is given to animals with a retained placenta in Burkina Faso, while a cold decoction of leaves and twigs is given to animals with haemorrhoids in Niger (Oyen, 2011).

\subsection{Timber and other uses}

The wood has acoustic properties making it suitable for sound boxes of drums and xylophones (Oyen, 2011). It is also used for making match-sticks, domestic appliances, door and window frames and fuel wood. The bark is used for making whistles. Stakes are planted to establish live fences in Sierra Leone. Containing tannins, the bark produces a brown dye. The white floss in the fruits of $B$. costatum is widely used for stuffing mattresses, pillows and cushions (Oyen, 2011). Flowers and leaves are valuable fodder for domestic animals, while the tree provides shade for grazing animals (Oyen, 2011). The species is an important bee forage (Orwa et al., 2009). Bombax costatum provides ecosystems services such as erosion control, soil improvement, fencing material and intercropping attesting to its agroforestry significance (Orwa et al., 2009). 


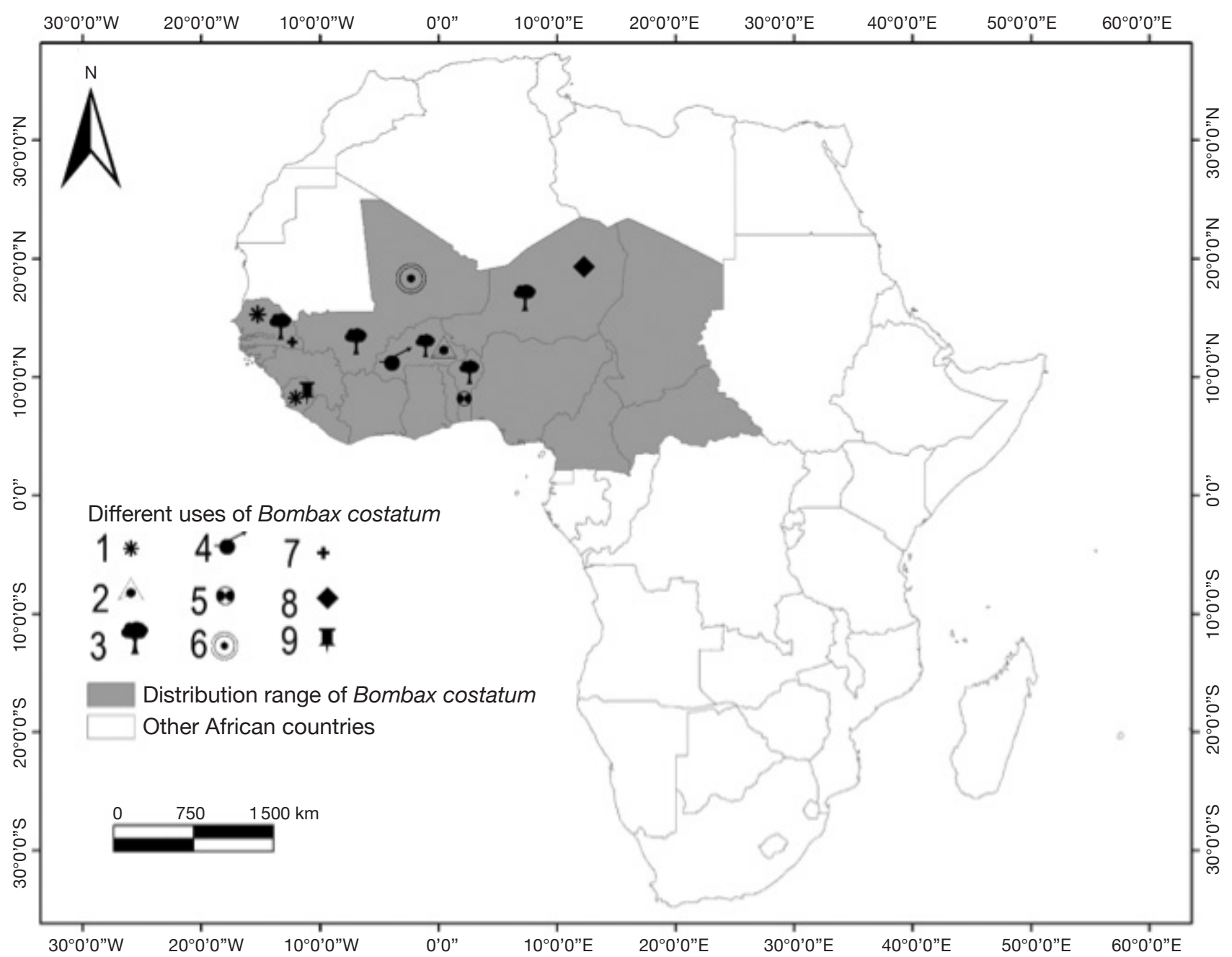

Figure 2. Patterns of nine common uses of Bombax costatum in West Africa - Répartition de neuf usages communs de Bombax costatum en Afrique de l'Ouest.

1. bark of stem and roots used for diuretic properties - écorces de tiges et racines utilisées pour leurs propriétés diurétiques; 2. roots and barks used for treatment of dizziness, dysentery and malaria - racines et écorces utilisées pour le traitement de vertiges, de la dysenterie et du paludisme; 3. flowers used in preparation of sauces - fleurs utilisées pour la préparation de sauces; 4. pounded leaves used against placenta retention in animals - feuilles pilées utilisées contre la rétention placentaire chez les animaux; 5. barks used against fever, skin disease, pain, abscess, oedema, hernia, epilepsy - écorces utilisées contre la fièvre, les maladies de la peau, les douleurs, les abcès, les zedèmes, les hernies et l'épilepsie; 6. barks and leaves and parts of other plants used as decoction against menstrual problems - écorces et feuilles en association avec des parties d'autres plantes utilisées en décoction contre les problèmes menstruels; 7 . leaves used with other plants-based drugs against leucorrhoea and diarrhoea - feuilles utilisées en association avec d'autres plantes contre la leucorrhée et la diarrhée; 8. leaves and twigs used as a cold decoction given to animals with pills - feuilles et rameaux donnés en décoction à froid aux animaux avec divers médicaments; 9. young plants used as living fences - jeunes plants utilisés comme clôtures vivantes.

\subsection{Nutritional and phytochemical properties}

Suitability of B. costatum for human and animal consumption is supported by its high protein content, low content of toxic substances and the amount of polyunsaturated fats in its seed oil (Orwa et al., 2009). In Niger the fruit was found to contain 20-25\% protein (Oyen, 2011). The seeds have high oil content (20\%). Iron and zinc were also found in high concentrations in flowers: $1.5 \mathrm{mg} \cdot \mathrm{g}^{-1}$ iron and $67.1 \mu \mathrm{g} \cdot \mathrm{g}^{-1}$ zinc (Maiga et al., 2005), suggesting that this species could be an interesting source of iron for humans in case of haemoglobin deficiency. Although the species is characterized by a high nutritional value (Kristensen \& Lykke, 2003), there is still a lack of detailed information on the nutritional content of this species especially in terms of human nutrition.

Atcholi et al. (2015) studied the species as a potential bio adhesive source in the development of formaldehyde-free particle board. In this study, mucilage and pectin fractions of the flower sepals were 
analyzed for monosaccharides, their identification and quantification. The aqueous extraction obtained and ethanolic precipitation, followed by ionic chromatography showed interesting qualitative results. Bombax costatum is an untapped reservoir of phytocompounds which may play a supportive role in the pharmaceutical field (Refaat et al., 2013). The fatty acid of its oil is composed of caproic acid (3\%), caprylic acid (7\%), palmitic acid (8\%), stearic acid $(3 \%)$, oleic acid $(49 \%)$, linoleic acid $(13 \%)$, rachidic acid (3\%), lignoceric acid (1-2\%), and others (13\%) (Oyen, 2011; Refaat et al., 2013).

\subsection{Socioeconomic importance}

Bombax costatum has a great socioeconomic importance (Ouédraogo et al., 2014) with interesting commercial value (Kristensen \& Lykke, 2003). The calyx is sold on local markets and hence constitutes an additional source of income in rural communities (Kristensen \& Lykke, 2003; Belem et al., 2007; Assogba et al., 2017). The monetary value of the calyces varied with their diameter and with the season. For instance in Burkina Faso, over the same period, their annual value per tree varied from 2.57 US\$ (tree of diameter size 10 to $25 \mathrm{~cm}$ ) to 26.10 US\$ (tree of diameter size $50 \mathrm{~cm}$ and above) (Ouédraogo et al., 2014). Prices predictably increase during the rainy season when stocks become low and demand high (Mertz et al., 2001). Oyen (2011) estimated that about 1,000 t of kapok from natural Bombax costatum stands were exported annually from francophone West Africa, suggesting high potential for business.

\section{PROPAGATION, GROWTH AND DEVELOPMENT}

The best way to propagate $B$. costatum is by direct seeding, although wildings may also be used (Oyen, 2011). Before sowing, the fibrous material covering the seed should be removed and the seed should then be immersed in boiling water and soaked in cold water for $24 \mathrm{~h}$ (Oyen, 2011). It is easy to produce the seedlings of B.costatum in nursery, but seeds seem difficult to keep for several years. However, it is unclear how long the seeds are viable and how long they can be conserved for future use as planting material. Seedlings are difficult to transplant despite their vigorous rooting ability (Oyen, 2011). According to this author, when the seedlings are adequately protected against fire and livestock, natural regeneration is easy and abundant. Assessing the regeneration pattern of the species in Burkina Faso, Ouédraogo \& Thiombiano (2012) observed an irregular structure in most of the studied populations.
In addition, high mortality was observed between the first and second year, followed by reduced mortality. It was concluded that " $B$. costatum seedlings showed potential for use in silviculture as evidenced by the fact that it showed high post-transplantation rates of survival and growth" (Ouédraogo \& Thiombiano, 2012). When natural regeneration is not easy, the stimulation of suckering under the mature trees can be recommended (Belem et al., 2008). The suckering represents the main and most suitable way of recruitment for B. costatum (Ouédraogo, 2006). Belem et al. (2008) investigating the suckering potential of the species, showed that the suckering can be induced by injuries to its roots at the beginning of the rainy season, and therefore lack of seeds is not a limiting factor for the species regeneration. While Belem et al. (2008) developed techniques to stimulate, control and optimize the suckering potential of B. costatum, Ouédraogo \& Thiombiano (2012) showed that B. costatum can regenerate about $95 \%$ by suckering in a relatively young stand. These show up favourable prospects for in situ conservation of the species.

Bombax costatum flowers after leaf fall in November to February (Orwa et al., 2009) and new leaves unfold from April onwards (Oyen, 2011). Under favourable conditions, trees start bearing fruit from the $6^{\text {th }}$ year onwards and fruit ripening begins in August-September (Orwa et al., 2009; Oyen, 2011). However, Oyen (2011) stated that trees often do not produce fruits due to fire-damage at the critical time of flowering in the dry season. Fruits mostly open while still on the tree and the lightweight seeds are spread by gravity and wind. A tree bears up to 1,500 fruits, each with $5-8 \mathrm{~g}$ of kapok. Under favourable conditions, $3-5 \mathrm{~kg}$ kapok per tree can be obtained from the $10^{\text {th }}$ year onwards (Orwa et al., 2009; Oyen, 2011).

\section{THREATS AND CONSERVATION}

Bombax costatum is threatened presumably because of its poor natural regeneration (Ouédraogo et al., 2006b), and also by the intensive harvesting of its flowers for domestic and commercial use as a vegetable (Belem et al., 2008). In Burkina Faso, the species is among the most preferred by the local population for its uses (Mertz et al., 2001) and is threatened because of the overexploitation of its different organs, mainly the calyx (Ouédraogo et al., 2014). Considering these threats and its great socioeconomic importance for local populations, B. costatum could be regarded as a species of high conservation priority (Kristensen \& Lykke, 2003; Sop et al., 2012). In spite of existing efforts towards its conservation, B. costatum is still under serious threat as a result of degradation of natural stands through: 
- flower harvesting which impedes the fructification;

- seedling destruction by farmers during the weeding in farmlands;

- lopping of mature trees for handicrafts;

- grazing of seedlings by the livestock, etc.

Yet it is important to note that neither the impact of the overharvesting of flowers nor the combined effect of all sources of threats has been explicitly quantified.

Nevertheless, several studies have reported that its rejuvenation in the degraded savanna parkland is inadequate to sustain production of flowers, fruits and leaves. In general, rural communities from sub-Saharan Africa domesticate multipurpose tree species in home gardens (Gautam \& Watanabe, 2004). This conservation option would be more appropriate for B. costatum as the way the species'conservation is now initiated in West Africa does not include its cultivation. While it is not clear whether its genetic diversity is threatened, it is under threat as an economic resource with no formal and active management strategy (Oyen, 2011). In any case, the genetic diversity of the species needs to be investigated to better inform conservation strategies and future genetic improvement and breeding.

Bombax costatum does not have yet an official conservation status on the IUCN Red List of Threatened Species. However, it is reported to be disappearing from the Sahel and Guinean woodland areas of its range. In Benin, it has been included on the National List of Benin Food forest vegetable resources (Codjia et al., 2003). Hahn-Hadjali \& Thiombiano (2000) mentioned that B. costatum is quoted as a species in regression in the east of Burkina Faso. According to Ouédraogo (2006), B. costatum has unstable population structures characterized by few seedlings in anthropogenized zones. Bombax costatum is classified as a vulnerable species and is among the species which could be highly threatened if adequate measures are not taken to ensure their conservation (Garzuglia, 2006).

\section{KNOWLEDGE GAPS AND FUTURE PERSPECTIVES}

This literature survey provides evidence that $B$. costatum is of great socioeconomic importance, yet threatened. As such there is a great challenge for its conservation. There is a lack of knowledge in the literature regarding the species occurrence in relation to the environmental factors. Yet, such information is important to inform decision making on current and future suitable habitats for the species conservation and domestication. As such, there is a need to investigate the species environment niche and important ecological drivers. Little is also known about the species management as an agroforestry species. Besides the calyx, and other uses mentioned as important by local people (Belem et al., 2008; Assogba et al., 2017), the species contribution to soil fertility could be an additional advantage, especially in sub-Saharan Africa where soil fertility is an acute agricultural issue (Saïdou et al., 2004). There is therefore a need to investigate the effect of its biomass production and root systems on soil fertility. For other economically important fruit species such as Anacardium occidentale L. and Mangifera indica L. pollinators enhance fruits yield (Abrol, 2012). This crucial role of pollinators is conceivable for B. costatum as reported by locals in Benin (see Assogba et al., 2017). However, the pollination biology of the species has to be properly investigated with the identification of the pollinators. The impact of these pollinators on the production of flowers and fruits can then be readily assessed. The outcomes of such investigations are relevant prerequisites for successful breeding programs. It is also important to determine the influence of the overharvesting and the debarking on the species reproductive performance. Investigations are also needed to determine the conditions for longterm preservation of seeds.

To maintain and increase the socioeconomic importance of B. costatum, more attention is essential concerning its conservation in the West African parklands. Remarkably, little information is available on the properties of the fibre obtained from the fruit, on the nutritional value as a vegetable and a fodder, and on its pharmacological composition. Future studies could address the nutritional and medicinal values of the species and its potential contribution to household income, as well as the efficient propagation methods to ensure that the species can be used sustainably. Eliciting the variation of the nutrient content of the species across ecological gradients is crucial for selection of best germplasm for specific purposes.

Genetic resources and genotypes of B. costatum are almost absent in national and international gene banks. This stands as a serious limitation for breeding programs, mainly for selection and improvement of wild morphotypes, and creation of varieties. Analysis of ecological and geographical distribution of genetic diversity based on molecular tools would help to increase knowledge on patterns and drivers of genetic diversity in $B$. costatum. Indeed, genotyping is a crucial step in a breeding program. Prior morphological and biochemical analyses will pave the way for molecular genetic studies and accelerate trait identification and selection of best morphotypes for cultivation. While improving this species, there might be losses of genetic diversity inherent to the domestication processes (Achigan-Dako et al., 2015) so that it is also important to develop strategies for effective in situlex situ conservation of its diversity. So far, little has been achieved on this species'conservation status, 
genetic diversity, breeding and domestication. Finally, B. costatum's potential for vegetative propagation could be examined in order to facilitate multiplication and extension of "plus genotypes" (Simons \& Leakey, 2004).

\section{CONCLUSIONS}

Bombax costatum is a useful plant resource that could help alleviate poverty. It has many benefits for local populations and a great potential for food and medicine. The calyx of the species is substantially used as food. However, conservation of this species is unlikely if nothing is done. By now, knowledge on the biology of the species, the current conservation status, the genetic and environmental factors affecting locally preferred traits as well as intra-specific variations remain unknown. For promoting sustainable use of B. costatum, proposals were suggested to deepen knowledge on the species in order to increase the flower production, and to ensure ex situ as well as in situ conservation.

\section{Acknowledgements}

We thank the Organization for Women in Science for the Developing World (OWSD) for supporting G.A. ASSOGBA through the OWSD Postgraduate Fellowship Programme. A.B.Fandohan was supported by the Alexander von Humboldt Foundation return fellowship no 3.4 - RKS - BEN/1155509 and equipment subsidy no $3.6-$ BEN/1155509. V.K. Salako was supported by an AGNES (African-German Network of Excellence in Science) Junior Research Grant.

\section{Bibliography}

Abrol D.P., 2012. Pollination biology: biodiversity conservation and agricultural production. New York, NY, USA: Springer.

Achigan-Dako E.G. et al., 2010. Traditional vegetables in Benin. Cotonou, Benin: Institut National des Recherches Agricoles du Bénin, Imprimeries du CENAP.

Achigan-Dako E.G. et al., 2015. Current knowledge and breeding perspectives for the miracle plant Synsepalum dulcificum (Schum. et Thonn.) Daniell. Genet. Resour. Crop Evol., 62, 465-476

Akoègninou A., Van der Burg W.J. \& Van der Maesen L.J.G., éds, 2006. Flore analytique du Bénin. Leiden, The Netherlands: Backhuys Publishers.

Arbonnier M., 2002. Arbres, arbustes et lianes des zones sèches d'Afrique de l'Ouest. $2^{\mathrm{e}}$ éd. Paris: MNHN/ CIRAD.

Assogba G.A., Fandohan A.B., Salako V.K. \& Assogbadjo A.E., 2017. Usages de Bombax costatum
(Malvaceae) dans les terroirs riverains de la réserve de biosphère de la Pendjari, République du Bénin. Bois For. Trop., 333(3), 17-33.

Atcholi K.E. et al., 2015. Opportunities of natural polymers in the biocomposites based from agro-resources: Grewia venusta mucilage and Bombax costatum calyx, two tropical plants like sources of natural binders for particle boards manufacturing. In: Proceedings of the $22^{e}$ Congrès Français de Mécanique, 24-28 aout 2015, Cité des Congrès, Lyon, France.

Aubréville A., 1950. Flore forestière soudano-guinéenne, Afrique occidentale française, Cameroun, Afrique équatoriale française. Paris: Société d'Éditions géographiques, maritimes et coloniales.

Bayala J., Kindt R., Belem M. \& Kalinganire A., 2011. Factors affecting the dynamics of tree diversity in agroforestry parklands of cereal and cotton farming systems in Burkina Faso. New For., 41, 281-296.

Belem B., 2009. Ethnobotanique et conservation de Bombax costatum Pel. \& Vuil. (faux kapokier) dans les systèmes de production agricoles du Plateau Central, Burkina Faso. Thèse de doctorat: Université de Ouagadougou (Burkina Faso).

Belem B. et al., 2007. Use of non wood forest products by local people bordering the "Parc National Kaboré Tambi”, Burkina Faso. J. Transdisciplinary Environ. Stud., 6(1), 1-21.

Belem B., Boussim I.J., Bellefontaine R. \& Guinko S., 2008. Stimulation du drageonnage de Bombax costatum par blessure des racines au Burkina Faso. Bois For. Trop., 295(1), 71-79.

Boffa J.-M., 2000. Les parcs agroforestiers en Afrique subsaharienne. Rome : FAO.

Chweya J.A. \& Eyzaguire P., 1999. The biodiversity of traditional leafy vegetables. Roma : IPGRI.

Codjia J.T.C., Assogbadjo A.E. \& Mensah M.R., 2003. Diversité et valorisation au niveau local des ressources forestières alimentaires du Bénin. Cah. Agric., 12, 321331.

Fandohan A.B. et al., 2015. Domesticating and conserving indigenous trees species: an ecosystem based approach for adaptation to climate change in sub-Sahara Africa. Rev. CAMES, 3(1), 55-60.

FAO, 2005. The state of food insecurity in the world: eradicating world hunger-key to achieving the millennium development goals. Roma: FAO.

Garzuglia M., 2006. Threatened, endangered and vulnerable tree species: a comparison between Forest Resources Assessment Program 2005 and the IUCN red list. Working Paper 108/E. Roma: FAO.

Gautam K.H. \& Watanabe T., 2004. Ethnosilvicultural knowledge: a promising foundation for integrating non-timber forest products into forest management. Himalayan J. Sci., 2(3), 55-58.

GBIF (Global Biodiversity Information Facility), 2017. GBIF Data Portal, https://www.gbif.org, (04/10/2018). 
Grubben G.J.H. \& Denton O.A., 2004. Plant resources of tropical Africa 2. Vegetables. Wageningen, The Netherlands: PROTA Foundation; Leiden, The Netherlands: Backhuys Publishers; Wageningen, The Netherlands: CTA.

Hahn-Hadjali K. \& Thiombiano A., 2000. Perception des espèces en voie de disparition en milieu Gourmantché (Est du Burkina Faso). Ber. Sonderforschungsbereichs, 268, 285-297.

Heubach K., 2011. The socio-economic importance of non-timber forest products for rural livelihoods in West African savanna ecosystems: current status and future trends. PhD thesis: Goethe-Universität in Frankfurt (Germany.)

Inngjerdingen K. et al., 2004. An ethnopharmacological survey of plants used for wound healing in Dogonland, Mali, West Africa. J. Ethnopharmacol., 92, 233-244.

Kristensen M. \& Balslev H., 2003. Perceptions, use and availability of woody plants among the Gourounsi in Burkina Faso. Biodivers. Conserv., 12, 1715-1739.

Kristensen M. \& Lykke A.M., 2003. Informant-based valuation of use and conservation preferences of savanna trees in Burkina Faso. Econ. Bot., 57(2), 203-217.

Lamine N., Sidibe A. \& Bayala J., 1995. Use and commercialization of non-timber forest products in Western Burkina Faso. In: Leakey R.R.B., Temu A.B., Melnyk M. \& Vantomme P., eds. Domestication and commercialization of non-timber forest products in agroforestry systems. Roma: FAO, 51-64

Lykke A.M., Mertz O. \& Ganaba S., 2002. Food consumption in rural Burkina Faso. Ecol. Food Nutr., 41, 119-153.

Maiga A., Diallo D., Bye R. \& Paulsen B.S., 2005. Determination of some toxic and essential metal ions in medicinal and edible plants from Mali. J. Agric. Food Chem., 53, 2316-2321.

Mertz O., Lykke A.M. \& Reenberg A., 2001. Importance and seasonality of vegetable consumption and marketing in Burkina Faso. Econ. Bot., 55(2), 276-289.

Millennium Ecosystem Assessment, 2005. Ecosystem and human well-being: biodiversity synthesis. Washington: World Resources Institute.

Ogbobe O., Ezeukwu A.O. \& Ozoh N.G., 1996. Physicochemical properties of seed and fatty acid composition of Bombax costatum seed oil. Riv. Ital. Sostanze Grasse, 73, 271-272.

Orwa C. et al., 2009. Agroforestree database: a tree reference and selection guide version 4.0, http://www. worldagroforestry.org/publication/agroforestree- database-tree-species-reference-and-selection-guideversion-40, (04/10/2018).

Ouédraogo A., 2006. Diversité et dynamique de la végétation ligneuse de la partie orientale du Burkina Faso. Thèse de doctorat : Université de Ouagadougou (Burkina Faso).

Ouédraogo A., Thiombiano A., Hahn-Hadjali K. \& Guinko S., 2006. Diagnostic de l'état de dégradation des peuplements de quatre espèces ligneuses en zone soudanienne du Burkina Faso. Sécheresse, 17, 485-491.

Ouédraogo A.\& Thiombiano A., 2012. Regeneration pattern of four threatened tree species in Sudanian savannas of Burkina Faso. Agrofor. Syst., 86, 35-48.

Ouédraogo I. et al., 2014. Productivité et valeur économique des calices de Bombax costatum Pellegr. \& Vuillet en zone soudanienne du Burkina Faso. Bois For. Trop., 319(1), 31-41.

Oyen L.P.A., 2011. Bombax costatum Pellegr. \& Vuillet. Record from PROTA4U. Wageningen, The Netherlands: PROTA.

Paré S. et al., 2010. Consumptive values and local perception of dry forest decline in Burkina Faso, West Africa. Environ. Dev. Sustain., 12, 277-295.

Refaat J., Desoky S.Y., Ramadan M.A. \& Kamel M.S., 2013. Bombacaceae: a phytochemical review. Pharm. Biol., 51(1), 100-130.

Robyns A., 1957. Le genre Bombax en Afrique tropicale. Bull. Jardin Bot. État Bruxelles, 27(4), 655-668.

Saïdou A. et al., 2004. Sustainable soil fertility management in Benin: learning from farmers. NJAS-Wageningen J. Life Sci., 52(3-4), 349-369.

Sieglstetter R., Hahn K. \& Wittig R., 2011. The use of woody species in northern Benin. Flora Vegetatio Sudano-Sambesica, 14, 19-23.

Simons A.J. \& Leakey R.R.B., 2004. Tree domestication in tropical agroforestry. Agrofor. Syst., 61, 167-181.

Sop T.K. et al., 2012. Ethnobotanical knowledge and valuation of woody plants species: a comparative analysis of three ethnic groups from the sub-Sahel of Burkina Faso. Environ. Dev. Sustainability, 14(5), 627649.

Taïta P., 2003. Use of woody plants by locals in Mare aux Hippopotames Biosphere Reserve in western Burkina Faso. Biodivers. Conserv., 12, 1205-1217.

World Bank, 2004. Sustaining forests: a development strategy. Vol. 1. Washington: World Bank.

(47 ref.) 